\title{
Erratum to: Social Accountability as an Innovative Frame in Civic Action: The Case of Rede Nossa São Paulo
}

\author{
Danielle Fabian Fiabane • Mário Aquino Alves • \\ Gabriela de Brelàz
}

Published online: 17 October 2013

(C) International Society for Third-Sector Research and The Johns Hopkins University 2013

\section{Erratum to: Voluntas \\ DOI 10.1007/s11266-013-9365-6}

This paper was inadvertently published without the full author list. The complete author list for this paper is: Danielle Fabian Fiabane, Mário Aquino Alves (corresponding author), Gabriela de Brelàz.

The online version of the original article can be found under doi:10.1007/s11266-013-9365-6.

D. F. Fiabane · M. A. Alves $(\bowtie) \cdot$ G. de Brelàz

Centro de Estudos em Administração Pública e Governo, Fundação Getulio Vargas, Av. Nove de Julho, 2029, $11^{\circ}$ andar, São Paulo, SP 01313-902, Brazil

e-mail: mario.alves@fgv.br 